\title{
History of Education Society 2005 Claude C. Eggertsen Dissertation Prize
}

The History of Education Society is please to announce the winner of the 2005 Claude C. Eggertsen Dissertation Prize is Hilary J. Moss, for her dissertation, "Opportunity and Opposition: The African-American Struggle for Education in New Haven, Baltimore, and Boston, 1825-1855." This award is given annually to the best dissertation in the history of education. The winner receives an honorarium of $\$ 1,000$, which will be presented at the banquet on October 22 at the Society's 2005 annual meeting in Baltimore. She will also be presenting her work in a special session at the conference.

Dr. Moss's dissertation persuasively revises the historiography of early national education. Using a wide variety of primary sources, she demonstrates that antebellum educational reform and opposition to black schooling were intimately related. Moss argues that in New Haven, Baltimore, and Boston, to varying degrees, common school reform provided white children from all classes and ethnicities the opportunity to become citizens; increasingly, it also reinforced a conception of citizenship synonymous with "whiteness" in which neither free nor enslaved black Americans could participate.

The Eggertsen Prize Committee included Kim Tolley (chair), Anne Meis Knupfer, and Victoria-María MacDonald. 